\title{
RUANG BERJALAN: SEJARAH PERENCANAAN PEDESTRIAN DI JAKARTA
}

\author{
Ratu Arum Kusumawardhani ${ }^{1}$, Karya Widyawati ${ }^{2}$, \\ ${ }^{1}$ Universitas Indraprasta PGRI, Program Studi Arsitektur \\ ratu.arum.ak@gmail.com \\ ${ }^{2}$ Universitas Indraprasta PGRI, Program Studi Arsitektur \\ widyawatik@yahoo.co.id
}

\begin{abstract}
When people habitat in a city, they must get easy access to move in all directions. Cities are always developing and so are the network systems that exist within them, but the human need to move by foot will always be there. Pedestrian paths become a network system for this movement and their existence also develops following the needs and growth of the city. This paper examines how the development of pedestrian path planning in Jakarta from time to time through historical approach. What paradigms underlie the planning of pedestrian paths in each period and the priorities taken by the decision makers at each periods. Such developments have brought Jakarta closer to a pedestrian-friendly city and have made Jakarta's pedestrian pathways a space for the aspirations of its people. Interpretation method used in this research by using online news data as the main source. It is important to know the process that occurs in Jakarta, considering its position as the capital city of the country and every planning and policy that occurs will always be a barometer of planning and policy for other cities in Indonesia.
\end{abstract}

Key Words: pedestrian pathways, pedestrian, pedestrian history, Jakarta

\begin{abstract}
Abstrak : Ketika manusia bertinggal di suatu kota, ia harus mendapatkan akses yang mudah untuk berpindah ke segala penjuru. Kota selalu berkembang begitu pula sistem jaringan yang ada di dalamnya, tetapi kebutuhan manusia untuk berpindah dengan menggunakan kaki akan selalu ada. Jalur pedestrian menjadi sistem jaringan untuk perpindahan tersebut dan keberadaannya juga turut berkembang mengikuti kebutuhan dan pertumbuhan kota. Tulisan ini mengulas bagaimana perkembangan perencanaan jalur pedestrian di Jakarta dari masa ke masa melalui pendekatan aspek kesejarahan. Paradigma apa saja yang melatari perencanaan jalur pedestrian di tiap periode dan prioritas yang diambil oleh pemegang keputusan pada tiap masa. Perkembangan seperti apa yang terjadi yang membawa Jakarta semakin dekat ke arah kota yang ramah bagi para pejalan kaki dan menjadikan jalur pedestrian di Jakarta menjadi ruang aspirasi masyarakatnya. Metode interpretasi digunakan dalam penelitian ini dengan menggunakan data berita daring sebagai sumber utama. Proses yang terjadi di Kota Jakarta ini penting untuk diketahui mengingat posisinya sebagai ibu kota negara dan setiap perencanaan serta kebijakan yang terjadi akan selalu menjadi barometer perencanaan dan kebijakan bagi kota kota lain di Indonesia.
\end{abstract}

Kata Kunci : jalur pedestrian, sejarah, Kota Jakarta

\section{PENDAHULUAN}

Suatu sore di awal tahun 2020 ketika aktivitas masih berlangsung normal belum terusik oleh pandemi virus COVID19, berjalan kaki menelusuri sepanjang jalur pedestrian Cikini Salemba menjadi momen yang menyenangkan. Selepas keluar dari area Stasiun Cikini, deretan penjaja jasa ojek online berbaur dengan deretan sepeda para penjaja makanan. Kepala saling terjulur, saling mencari, antara calon penumpang dan pengemudi. Kendaraan yang melintas menahan lajunya, terutama di menit menit sibuk ketika orang banyak menyeberang. Riuh, tapi terasa begitu hidup.

Bergeser beberapa langkah, jalur pejalan kaki tersebut terasa lebih tenang. Kita dapat berjalan perlahan sambil menikmati suasana kota. Mengamati deretan bangunan lama seperti bangunan kampus bergaya internasional dan gedung bioskop ikon jalan Cikini, Metropole, yang terinspirasi oleh gaya art deco. Gedung megah yang kontras dengan para pedagang sate pikul yang jongkok menempel dinding pagar di naungan pohon rindang. Sate pikul yang membawa ke kenangan masa kecil, saat para pedagang itu masih berjualan keliling kampung sambil meneriakan dagangannya dengan unik, "TTeeeeeeee!!!". Berjalan menjadi semakin menyenangkan ketika indera penciuman dibelai aroma gurih lemak daging dan aroma manis kecap menetes di atas arang. Tetapi sepersekian detik kemudian melompat dikagetkan oleh kendaraan roda dua 
yang menyerobot naik ke trotoar untuk menghindari lampu merah. Motor yang masih bisa menyelinap lincah walau terhalang deretan tiang pembatas jalan.

Memasuki Jalan Diponegoro, berjalan kaki terasa lebih nyaman. Jalur pejalan kaki yang lebih lebar, bersih tanpa pedagang kaki lima, hanya sedikit orang lalu lalang atau duduk di kursi besi yang berderet teratur di sana. Jalur yang nyaman dipandang tetapi panas, tidak terdapat naungan pohon rindang serta ditambah padatnya kendaraan dan hembusan asap knalpot membuat kita harus berpikir ulang untuk menghabiskan waktu duduk di situ. Berbeda dengan yang terjadi di sepenggal pedestrian di sisi Jalan Salemba. Selalu ada kerumunan aneka ragam manusia di sekitar jembatan penyeberangan yang terletak dekat kampus Universitas Indonesia, saling asing satu sama lain tapi berbaur berbagi ruang di penggal yang sama. Semakin malam semakin ramai, pedagang makanan menggelar dagangannya bahkan ada pedagang yang hampir menutup habis lebar trotoar. Selain pedagang, mereka yang lalu lalang hanyalah mereka yang singgah, datang sejenak, berlalu dan pergi.

Merasakan pengalaman di jalur pedestrian antara Cikini - Salemba di awal tahun 2020, dan perubahan hasil dari penataan terakhir, memunculkan keingintahuan lebih lanjut tentang jalur pedestrian di Jakarta. Dari penelitian terdahulu, banyak yang mengulas jalur pedestrian baik yang mengambil kasus di kota Jakarta maupun Indonesia secara keseluruhan yang berpusat pada sisi perencanaan yang terkait langsung dengan kenyamanan pengguna. Umumnya penelitian tersebut mengulas tentang aspek rancangan yang paling sesuai dan nyaman bagi para pengguna. Seperti yang dilakukan oleh Pohan dan Manullang (2018) ketika membahas tentang prioritas indikator dalam perencanaan pejalan kaki dan Malik Al Karim (2019) yang membahas tentang analisis fisik penggunaan jalur pedestrian sebagai fasilitas publik. Penelitian terkait jalur pedestrian dengan pendekatan lain dilakukan oleh Prima dan Prayogi (2020) yang membahas tentang kajian perilaku pejalan kaki di kawasan Transit Oriented Development (TOD), pola perencanaan kota yang menjadi trend sekarang.

Penelitian terdahulu tersebut memberikan gambaran bahwa jalur pedestrian berkembang dan terus menerus ada pendekatan baru yang dilakukan dalam pengembangannya. Sehingga memunculkan rasa ingin tahu akan fungsi dan makna pedestrian di dalam perencanaan kota
Jakarta, dan cerita apa yang berada di belakangnya. Dengan menggunakan pendekatan sejarah, tulisan ini mencoba mengulas perencanaan penataan pedestrian dari masa ke masa. Paradigma apa saja yang melatari perencanaan di tiap periode dan prioritas yang diambil oleh pemegang keputusan pada masa itu. Proses yang terjadi di Kota Jakarta ini penting untuk diketahui mengingat posisinya sebagai ibu kota negara dan setiap perencanaan serta kebijakan yang terjadi akan selalu menjadi barometer perencanaan dan kebijakan bagi kota kota lain di Indonesia.

\section{METODOLOGI}

Metode yang digunakan dalam menyusun tulisan ini adalah metode interpretasi dengan menggunakan berita daring sebagai sumber utama. Data dikumpulkan dari berbagai website pemberitaan nasional yang memiliki reputasi baik dan juga melalui kanal resmi pemerintahan. Data diurutkan sesuai dengan periodesasi pemerintahan paska ditetapkannya Jakarta sebagai ibukota negara. Data tersebut yang kemudian disandingkan untuk dianalisis untuk melihat terjadinya perubahan kebijakan dan prioritas dari masing masing periode pemerintahan di Jakarta.

\section{HASIL DAN PEMBAHASAN}

\section{Ruang Berjalan}

Peran sebuah kota adalah menyediakan beragam kemungkinan bagi penduduknya untuk saling terhubung dengan cara yang teratur . Mereka harus dapat berpindah dengan mudah ke segala penjuru kota. Kota pasti akan bertumbuh, tetapi kebutuhan manusia untuk mendapatkan akses yang mudah ke segala penjuru kota dengan menggunakan kaki akan selalu ada. Semakin besar skala sebuah kota, maka akan semakin kompleks pula jaringan yang ada di dalamnya termasuk jaringan yang bersifat mekanikal dan otomatis. Sebuah kota yang baik akan mengatur jaringan yang ada di dalamnya berdasarkan skala manusia, dengan menempatkan jaringan yang memiliki kecepatan lebih tinggi berada di bagian dalam atau bawah tanah, dan yang lebih lambat menempati bidang permukaan. Ruang untuk manusia berjalan adalah jaringan yang pergerakannya paling lambat, sehingga ia akan selalu berada paling atas dimana manusia dapat merasakan bertinggal dan menempati suatu tempat atau in place. 
Ruang untuk berjalan atau jalur pedestrian bila ditelusuri, memiliki sejarah yang panjang. Sejarah jalur pedestrian merupakan bagian yang tidak terpisahkan dari sejarah jalan. Ia dikatakan tidak memiliki makna ketika berdiri sendiri, tetapi akan menjadi organ yang sangat vital ketika tersusun dalam satu entitas dengan bangunan dan jalan di sebelahnya ${ }^{1}$. Sebelum kota mengenal sistem jalan, jalur pedestrian dikatakan sebagai sistem transportasi atau penghubung yang dikenal terlebih dahulu. Banyak nama untuk menyebut pedestrian, beberapa istilah lain yang umum digunakan di Indonesia antara lain adalah trotoar dan jalur pejalan kaki. Pedestrian berasal dari bahasa latin pedester yang memiliki arti bepergian dengan menggunakan kaki , sedangkan trotoar yang berasal dari bahasa Perancis trottoir memiliki arti bagian tepi jalan yang ditinggikan tempat orang berjalan. Di dalam sejarah permukiman manusia, pedestrian adalah penghubung dan ruang sosial yang pertama kali terbentuk secara alami sebelum kemudian berkembang menjadi sistem dan hirarki jalan ketika permukiman tersebut berkembang menjadi kota. Pedestrian tertua ditemukan di Asia Kecil di permukiman Catal Huyuk (Abad ke 7 - 6 Sebelum Masehi) yang menggunakan atap bangunan sebagai pedestrian tempat bergeraknya manusia, dan di Hacilar yang memanfaatkan gang - gang sempit antar bangunan sebagai pedestrian .

Peradaban Romawi Kuno mengenal konsep jalur pedestrian yang mereka sebut semita, yang kemudian tidak lagi digunakan sampai kemudian muncul kembali di Inggris pada akhir abad ke 18. Ketika itu jalur pedestrian diperkenalkan kembali dan menjadi bagian pengembangan perencanaan jalan. Konsep awal pedestrian di Inggris terkait dengan kesehatan kota, sistem jaringan limbah kota disusun bertingkat di bawah permukaan tanah dan kemudian ditutupi dengan paving yang ditinggikan dan dapat digunakan untuk orang berjalan. Pola ini kemudian diikuti oleh kota Paris sejak tahun 1830 di bawah pengawasan Rambuteau, tokoh yang meletakan landasan dasar untuk kemudian dilanjutkan oleh Haussmann ketika melakukan perombakan besar besaran atas kota Paris. Dalam program perbaikan kota yang dilakukan Haussmann, perubahan yang paling terkenal adalah pada penataan jalannya terutama pada boulevard atau poros jalan utama yang

1 Kostof dalam The City Assembled p189 dan Jacobs dalam The Death and Live of American Cities menjelaskan hal yang serupa tentang entitas jalur pedestrian dilengkapi dengan deretan pohon rimbun dan jalur pedestrian yang lebar untuk dilalui oleh pejalan kaki dengan nyaman.

Munculnya gerakan arsitektur modern, tak luput menyentuh pula rancangan jalur pedestrian. Salah satu pola yang ditawarkan adalah pemisahan secara tegas jalur kendaraan, pejalan kaki dan bangunan yang kemudian menyusunnya secara vertical. Konsep streetless urbanity seperti yang ditawarkan oleh Le Corbusier dalam Ideal City. Le Corbusier melihat arah perkembangan kota yang akan mengikuti perkembangan teknologi kendaraan, sehingga dibutuhkan ruang ruang untuk pergerakan yang sangat cepat. Menurutnya, sebuah kota yang dibuat untuk pergerakan yang cepat adalah kota yang dibuat untuk sukses, konsep jalan layang dan jalur bebas hambatan yang membelah langit kota diperkenalkan, pedestrian bukan lagi bagian yang menjadi satu dengan jalan.

Konsep kota modern dengan sistem jalan seperti di atas, menjadi model yang banyak ditiru atau diterapkan di kota kota dunia, tidak terkecuali di Jakarta. Tetapi konsep tersebut mendapat kritik dari para penggerak new urbanism yang menganggap pendekatan modern tidak humanis. Salah satu tokoh penggerak new urbanism, Jane Jacobs, mengkritisi dengan mencoba memperlihatkan peran penting jalur pedestrian di sebuah kota melalui kebutuhan dan perilaku penggunanya. Secara keseluruhan, Jacobs mengkritisi pola perencanaan kota yang mengikuti konsep perencanaan modern yang lebih terfokus pada menempatkan kota sebagai mesin ekonomi. Menurutnya, di dalam kehidupan nyata, vitalitas suatu kota justru terletak pada masyarakatnya ketika mereka bergerak dan beraktivitas di ruang yang mereka tinggali. Jacobs kemudian berusaha membangun argumentasi dengan memperlihatkan proses yang terjadi di jalur pedestrian, memperlihatkan kebutuhan mendasar yang dari penduduk kota, interaksi sosial yang mungkin terbangun, dan bagaimana mereka dapat memainkan peranan penting di dalam fungsi kontrol.

Di Indonesia sendiri, jalur pedestrian diatur menjadi bagian dari dua sistem yaitu sebagai bagian dari sistem penataan jalan raya dan sistem tata ruang. Dalam Undang Undang No. 22 Tahun 2009 Tentang Lalu Lintas Angkutan Jalan, diatur hak keamanan dan keselamatan pejalan kaki 
ketika menggunakan sarana jalan. Sedangkan pada Undang Undang No. 26 Tahun 2007 Tentang Penataan Ruang, sarana jaringan pejalan kaki diamanatkan di dalam perencanaan tata ruang wilayah kota. Dalam tataran pelaksanaan, undang - undang ini diperjelas dalam peraturan turunannya berupa peraturan pemerintah, peraturan menteri, dan di tingkat daerah berdasarkan ke dua undang-undang di atas dapat dibuat peraturan tersendiri sesuai permasalahan dan kebutuhan yang dihadapi di masing - masing daerah. Secara umum, pranata tersebut mengatur bagaimana jalur pedestrian di Indonesia dapat dimanfaatkan, yaitu sebagai jalur pejalan kaki, ruang sosial, ruang pamer dan ruang bagi usaha kecil yang secara terinci diatur menurut lokasi, lebar jalur pedestrian, dan kebijakan pemerintah setempat.

Standar tentang tipe, bentuk, ukuran dan pemanfaatan jalur pedestrian di Indonesia pertama kali di susun tahun 1990 dalam bentuk Standar Nasional Indonesia, Petunjuk Pelaksanaan Trotoar No. 07/T/BNKT/19902 . Standar yang disusun oleh Badan Penelitian dan Pengembangan Departemen Pekerjaan Umum ini berupa panduan teknis pembuatan trotoar sebagai bagian dari sistem jalan raya, standar yang dua puluh empat tahun kemudian diperbaharui menjadi Pedoman Penyediaan dan Pemanfaatan Prasarana dan Sarana Ruang Pejalan Kaki di Kawasan Perkotaan yang menjadi dokumen pelengkap dari Peraturan Menteri Pekerjaan Umum No. 03/PRT/M/2014 dengan judul yang sama. Peraturan terbaru yang dimiliki Indonesia ini sudah lebih komprehensif dalam mengatur standar yang harus dipenuhi oleh jalur pedestrian yang diharapkan menjadi acuan dan panduan praktis bagi pemerintah kota dalam menata ruangnya. Azaz kesetaraan sudah jauh lebih diperhatikan bagi mereka yang berkebutuhan khusus, dan mendorong agar dibentuknya ruang bagi pejalan kaki yang nyaman dan humanis untuk mereka beraktivitas di perkotaan.

\section{Menuju Jakarta}

5 Juli 1959, Dekrit Demokrasi Terpimpin ditandatangani sekaligus menandai awal dimulainya pembangunan Jakarta sebagai sebuah kota modern. Di masa demokrasi terpimpin ini, visi Presiden Soekarno untuk mewujudkan Jakarta sebagai kota modern yang dapat mempersatukan bangsa sekaligus mercusuar dari bangsa yang

${ }^{2}$ Pembaruan SNI dilakukan di Pedoman Teknis Perekayasaan Fasilitas Pejalan Kaki di Wilayah Kota, sedang bangkit, mulai dilakukan. Di bawah kepemimpinan Gubernur Soemarno Sosroatmodjo, visi tersebut satu persatu dilakukan, dan di masa kempemimpinannya ini (1960 - 1964) Kota Jakarta ditetapkan sebagai ibukota negara. Momen puncak periode ini adalah ketika Jakarta ditetapkan sebagai tuan rumah Asian Games tahun 1962, persiapan fasilitas olah raga dan penunjangnya mendorong pengembangan Jakarta ke arah selatan dan poros jalan Sudirman Thamrin dibangun sebagai jalur penghubung utama .

Membelah Jakarta pada poros utara selatan dari kawasan Lapangan Merdeka hingga Kebayoran Baru, Jalan Sudirman Thamrin menampilkan wajah modern kota Jakarta. Jalan lebar terdiri dari tiga lajur untuk jalur cepat dan satu lajur untuk jalur lambat yang disebutkan sebagai broad avenue, menjadi salah satu yang dijual pada buku panduan turis tahun tersebut. Tetapi jalan yang lebar tersebut tidak seluruhnya dilengkapi dengan jalur pedestrian melainkan hanya pada simpul simpul tertentu tempat berlangsungnya kegiatan Asian Games tersebut (gambar 1). Di bagian jalan yang lain, masyarakat pejalan kaki bercampur dengan kendaraan bermotor, becak dan sepeda (gambar 2 dan 3). Di periode ini, fungsi pedestrian belum sepenuhnya untuk melayani kebutuhan para pejalan kaki melainkan lebih pada fungsi estetis di bagian tertentu kota.

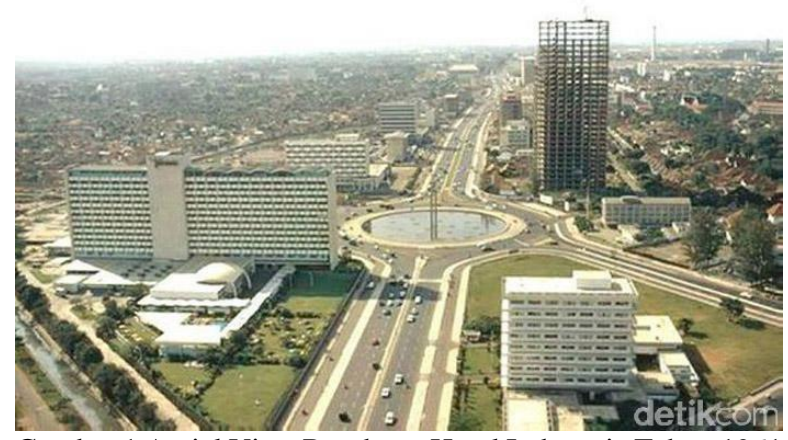

Gambar 1 Aerial View Bundaran Hotel Indonesia Tahun 1961 (Sumber: detik.com)

SK.43/AJ 007/DRJD/97 tetapi belum sekomprehensif sebagaimana Pedoman Teknis yang diterbitkan di tahun 2014 


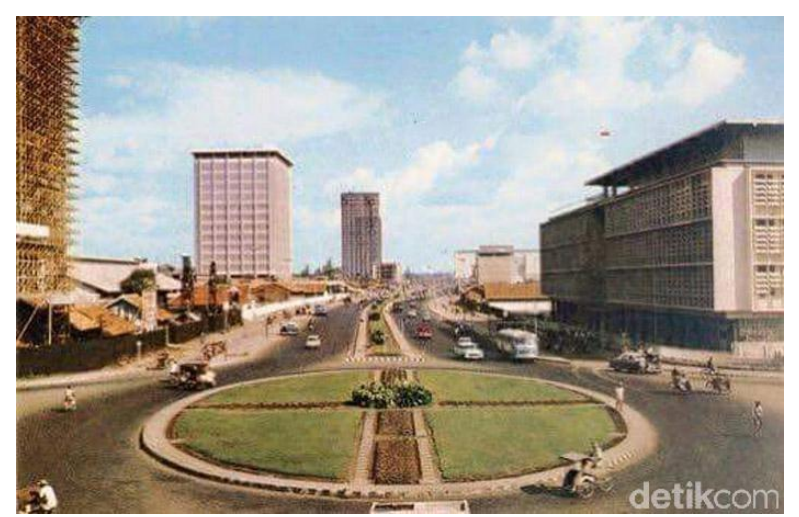

Gambar 2 Aerial View Bundaran Bank Indonesia Tahun 1961 (Sumber: detik.com)

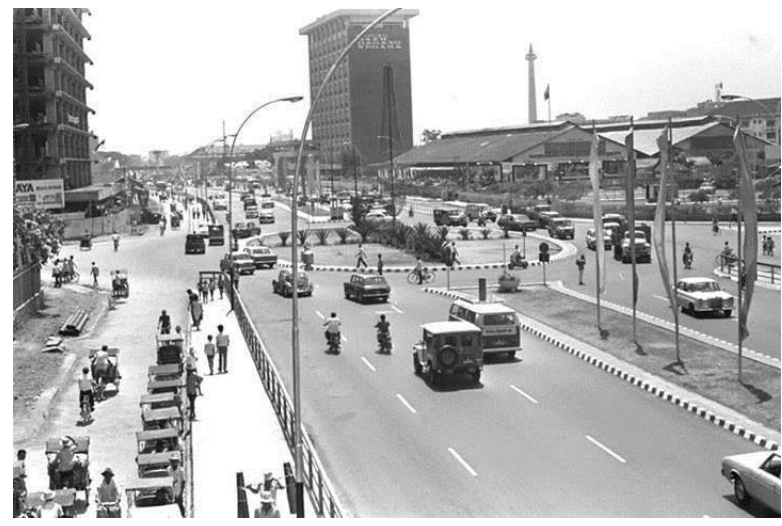

Gambar 3 Para pejalan kaki yang bercampur dengan kendaraan di Jalan Thamrin tahun 1962 (sumber: captainhuntz.wordpress.com)

Perhatian bagi para pejalan kaki mulai diberikan di masa pemerintahan Gubernur Ali Sadikin $(1966$ - 1975) . Gubernur yang terkenal dengan kampung improvement programnya yang lebih dikenal sebagai Proyek Mohammad Husni Thamrin (MHT) menitikberatkan programnya pada pembangunan infrastruktur. Ia menyusun program pengembangan kota yang sistematik yang mengutamakan pada perencanaan utilitas umum seperti: sanitasi, air bersih, pengumpulan sampah, pedestrian, pengembangan jalan, penataan bangunan dan jalur keselamatan kebakaran. Jalur pejalan kaki yang menjadi bagian dari programnya ini tetapi bukanlah jalur pejalan kaki yang berada dipermukaan dan tempat orang berjalan melainkan dalam bentuk jembatan pedestrian tempat orang menyeberang di titik titik jalan kota Jakarta yang mulai padat kendaraan.

Langkah yang sudah dimulai oleh Ali Sadikin ini tetapi kemudian berhenti dan tidak dilanjutkan oleh gubernur penggantinya. Bahkan di tahun 1989 di masa pemerintahan Gubernur Wiyogo Atmodarminto, beliau menyatakan keengganannya untuk membangun lebih banyak jalur pedestrian. Salah satu alasannya adalah banyaknya pedagang yang memanfaatkan jalur pedestrian dan menjadikan tampilan kota Jakarta menjadi kumuh . Di periode ini, umum dilihat jalur pedestrian yang dipagari dan bahkan dililit dengan kawat berduri sehingga tidak dapat dilalui oleh pejalan kaki. Jalur pedestrian lebih difungsikan sebagai etalase kota, perpanjangan dari halaman bangunan atau ruang privat.

Tahun 2000 terjadi perubahan arah kebijakan dalam penataan kota Jakarta. Gubernur Sutiyoso yang menjabat pada masa itu menggagas pilot project jalur pedestrian yang dapat diakses oleh umum sepanjang koridor Sudirman Thamrin. Visinya adalah membangun kesadaran akan potensi jalur pedestrian modern sebagai fasilitas kota. Fitur baru yang ramah pengguna seperti jalur berjalan yang lebar, penuntun arah tactile, ram yang mudah diakses, dan railing $S$ untuk mencegah pengendara motor naik ke jalur pedestrian mulai diterapkan. Jalur pedestrian ini juga terhubung dengan sistem transportasi Trans Jakarta busway yang dikembangkan di periode yang sama. Perencanaan jalur pedestrian ini dilakukan oleh Dinas Bina Marga yang merupakan bagian dari Dinas Pekerjaan Umum, yang kemudian menyiapkan jalur pedestrian dengan implementasi yang sistematik di Jakarta, yang jauh lebih baik dari yang ada sebelumnya .

Kekurangan dari penataan di periode ini adalah tidak dilakukan pendataan jalur pedestrian saat itu sehingga perbaikan dan pemeliharaannya tidak dilakukan dengan baik. Ditambah dengan rambahan pengendara bermotor jumlah jalur pedestrian yang mudah diakses tersebut menurun dengan cepat, yang membuatnya tidak lagi dapat digunakan dengan semestinya. Di sisi lain, dilakukannya penataan jalur pedestrian ini memunculkan partisipasi masyarakat kelas menengah yang memulai gerakan untuk berjalan kaki dan bersepeda. Komunitas komunitas dibentuk seperti koalisi pejalan kaki dan Bike2Work, serta organisasi akar rumput Urban Guerilla yang bergerak mendukung dibangunnya jalur pedestrian yang mudah diakses serta mengedukasi masyarakat pengguna terutama yang berkebutuhan khusus. Munculnya komunitas komunitas tersebut menjadi sistem kontrol sebagaimana yang dikatakan oleh Jacobs. Sistem yang muncul dari partisipasi masyarakat secara sukarela, lebih efektif dalam menjaga keberlangsungan jalur pedestrian yang dibangun pemerintah kota.

Kebiasaan berjalan kaki dan bersepeda yang mulai berkembang di tengah masyarakat melahirkan konsep Car Free Day atau hari bebas kendaraan dengan menutup jalan utama Sudirman 
- Thamrin untuk digunakan oleh masyarakat melakukan kegiatan sosialnya seperti kegiatan olahraga, seni, atau bersosialisasi. Konsep yang diperkenalkan di masa pemerintahan Sutiyoso ini awalnya hanya dilakukan untuk memasyarakatkan gagasan mengurangi polusi dan membangun kehidupan urban yang berkelanjutan, tetapi kemudian dibawah Gubernur Fauzi Bowo, kegiatan ini dijadikan kegiatan bulanan lalu mingguan.

Dapat dikatakan bahwa di masa pemerintahan Gubernur Sutiyoso, perencanaan jalur pedestrian yang bukan hanya sekedar pelengkap estetik kota melainkan fungsional dan mudah diakses mulai diterapkan. Kebijakan gubernur penerusnya tetap berdasar pada visi yang digagas di masa pemerintahan Sutiyoso. Perencanaan dan pelaksanaan yang ditugaskan ke Dinas Bina Marga membuat perencanaan dapat dilakukan secara jangka panjang dengan prioritas dan arah yang jelas. Menurut Kepala Dinas Bina Marga Pemerintah Provinsi DKI Jakarta Yusmada Faisal, perencanaan penataan jalur pedestrian di Jakarta akan terus berlangsung walaupun berganti kepemimpinan ${ }^{3}$.

Perencanaan lanjutan jalur pedestrian di Jakarta di masa kepemimpinan Gubernur Basuki Tjahaja Purnama selain mengikuti rencana yang sudah ada yaitu penataan di seluruh wilayah kota Jakarta, memiliki agenda utama yaitu mengikuti rencana pembangunan MRT Jakarta. Jalur pedestrian yang dirancang merupakan pelengkap yang menghubungkan ke akses masuk stasiun yang berada di bawah tanah. Pelebaran jalur pedestrian menjadi keharusan agar dapat menampung penumpang yang keluar masuk dari stasiun, sehingga untuk kebutuhan tersebut jalur lambat kendaraan kemudian dihilangkan. Model pedestrian seperti yang terdapat di kota kota Eropa maupun Amerika menjadi acuan mimpi Basuki Tjahaja Purnama, yaitu jalur pedestrian dengan lebar mencapai 10 meter yang direncanakan lengkap dengan area berdagang yang dapat disewakan kepada pedagang kaki lima atau pengusaha kecil yang ditata menyerupai kafe atau restoran. Tingginya biaya pembangunan jalur pedestrian disiasati dengan bantuan dana penggunaan kompensasi koefisien lantai bangunan (KLB) pihak swasta . Pengembangan jalur Sudirman - Thamrin sebagai kawasan terpadu Transit Oriented Development (TOD) dianggap memiliki nilai jual yang akan mendorong peran serta swasta untuk berpartisipasi di dalam penataan pedestrian, termasuk membuka pagar bangunan mereka yang menjadi pembatas antara ruang publik dan ruang private .

Perencanaan yang belum terlaksana di masa kepemimpinan Basuki Tjahaja Purnama tetap berlanjut di masa kepemimpinan Anies Baswedan. Pemerintah Provinsi DKI Jakarta sendiri di tahun 2017 menargetkan untuk membangun jalur pedestrian sepanjang 2600 kilometer pada 48 lokasi yang tersebar di 42 kecamatan di Jakarta yang dilakukan secara bertahap. Di dua tahun pemerintahannya, Anies kian mencanangkan Jakarta sebagai kota ramah pejalan kaki . Dari tahun 2017 hingga 2019 telah dibangun dan direvitalisasi jalur pedestrian sepanjang 134 kilometer. Ukuran jalur pedestrian diperlebar dan dipercantik, dengan Jalur Sudirman Thamrin masih digunakan sebagai kawasan percontohan. Di tahun 2019 terdapat 10 lokasi trotoar yang direvitalisasi, diantaranya adalah sepanjang koridor Cikini Raya, Jalan Pangeran Diponegoro, Jalan Kramat Raya dan Salemba hingga ke Jalan Matraman Raya. Poros jalan yang membuka rasa ingin tahu saya lebih lanjut tentang jalur pedestrian di Jakarta.

Dalam penataan jalur pedestrian ini terjadi kontroversi di tengah masyarakat ketika dirubuhkannya jembatan penyeberangan di dekat Bundaran Hotel Indonesia yang kemudian digantikan dengan pelican cross dan pengurangan jalur kendaraan bermotor yang digunakan untuk pelebaran pedestrian. Termasuk yang terjadi di sepanjang jalan Cikini - Diponegoro - Salemba Kramat hingga Matraman. Sebagian masyarakat mengeluhkan pengurangan jalur tersebut, tetapi pemerintah kota berpendapat bahwa kemacetan lebih disebabkan oleh pengendara bermotor, bukan pejalan kaki. Kota seharusnya lebih memiliki keberpihakan kepada para pejalan kaki. Usaha pelebaran trotoar yang dilakukan Anies Baswedan didukung oleh Mantan Gubernur Sutiyoso yang menganggap langkah kebijakan yang dilakukan Anies sudah tepat. Persetujuan yang bukan tanpa kritik, karena menurutnya pemerintah kota terlalu lunak, harusnya dapat menekan para pemilik bangunan gedung di sepanjang jalur pedestrian untuk memberikan sebagian lahannya untuk pelebaran jalur pedestrian tersebut. Konsep yang pernah digagasnya saat memimpin Jakarta tapi tidak sepenuhnya berhasil.

3 Ide yang sama yang dilontarkan di masa pemerintahan Sutiyoso tetapi belum terealisasi 
Berkembangnya media sosial dan kian aktifnya masyarakat kota beraktivitas di ruang luar, menjadi kombinasi yang menginspirasi pemerintah kota menyiapkan ruang ruang interaksi sosial yang menjadi bagian dari jalur pedestrian. Jalur pedestrian buka hanya sekedar tempat berjalan tetapi dilengkapi dengan kantung kantung yang dapat digunakan untuk berolahraga, pameran, atau pertunjukan musik kecil. Beberapa bidang dilengkapi dengan elemen yang menarik warga kota untuk melintas atau sekedar berswafoto seperti pada jembatan pedestrian di Jalan Sudirman dan atau Terowongan Kendal. Perencanaan di tiap tiap segmen juga mulai dibuat tematik. Seperti poros Cikini Raya - Kramat Raya dan Salemba Raya yang direvitalisasi untuk menjadi trotoar ekspresi kreativitas . Partisipasi pembangunan yang melibatkan warga juga diterapkan, contohnya pada koridor Cikini Kramat Raya - Salemba yang melibatkan Institut Kesenian Jakarta dan Komunitas Seni Budaya. Arah perkembangan jalur pedestrian Jakarta kian mendekati amanat yang tercantum dalam undang - undang dan makin mengoptimalkan kekuatan masyarakat untuk mempertahankan vitalitas dan kontrol di atasnya.

Sebagian dari jalur pedestrian tersebut baru selesai tahap pembangunan dan atau masih dalam proses pelaksanaan, masih memerlukan waktu untuk pembuktian seberapa tingkat keberhasilan pemerintah kota Jakarta dengan kebijakan terbarunya. Tantangan lain yang muncul sejak awal tahun ini adalah pandemi Covid19 yang membuat pemerintah kota Jakarta mengambil kebijakan Pembatasan Sosial Berskala Besar (PSBB) yang utamanya diterapkan pada fasilitas publik termasuk pedestrian. Pandemi yang belum diketahui kapan akan selesai ini memunculkan tatanan baru kehidupan yang diistilahkan sebagai new normal yang mulai diterapkan oleh pemerintah Indonesia sejak 1 Juni 2020 dengan Kota Jakarta menjadi salah satu lokasi percontohan. Tatanan yang menitikberatkan pada protokol hidup sehat dan menjaga jarak tersebut berpengaruh pada kebiasaan dan perilaku masyarakat yang menuntut adanya kontrol dan disiplin yang tinggi. Untuk jalur pedestrian, akan membutuhkan adaptasi perilaku, penyesuaian rancangan dan mungkin penambahan elemen penunjang protokol kesehatan, pekerjaan rumah tambahan yang harus segera dilakukan oleh pemerintah kota Jakarta. Penyelesaian yang bukan hanya sebatas fisik, karena yang lebih sulit adalah melakukan perubahan perilaku. Penerapan PSBB dan ketetapan new normal bagi sebagian masyarakat Jakarta masih diabaikan, rasa takut terhadap pandemi tidak seseram urusan ekonomi. Pemanfaatan jalur pedestrian erat dengan fungsi kontrol, meminjam pemikiran Jacobs, kontrol yang paling baik masih tetap berada pada partisipasi aktif pengguna pedestrian itu sendiri.

\section{PENUTUP}

\section{Sudikah berjalan?}

Jacobs menyatakan, ketika jalan tersusun dengan menarik, kota akan terlihat menarik. Begitu pula ketika jalan tersusun secara membosankan, maka kota juga akan terlihat membosankan. Pandangan yang harus kita amini, karena persinggungan kita dengan ruang kota selalu dimulai dari jalan, dan jalur pedestrian menjadi bagian yang menyatu di dalamnya. Dari sekilas data yang ditemukan, Jakarta ternyata tertinggal jauh di dalam perencanaan dan penataan jalur pedestrian kotanya. Kecenderungan perencanaan yang memperhatikan keamanan, kenyamanan, dan kesetaraan para pejalan kaki baru terjadi dalam beberapa tahun belakang ini, dengan dukungan pedoman pelaksanaan yang lebih komprehensif. Pola penataan yang dilakukan akhir akhir ini merupakan bentuk kompromi antara menata estetika kota dengan mencoba menyediakan pelayanan yang lebih baik.

Untuk kota Jakarta, kita masih harus bersabar untuk dapat menikmati jalur pedestrian yang baik, yang menyebar merata di seluruh penjuru kota. Keterbatasan anggaran pembangunan yang disiasati dengan menarik dana kompensasi koefisien lantai bangunan dari gedung - gedung tinggi yang ada di Jakarta, di satu sisi menyelesaikan masalah dengan (lebih) cepat tetapi mencederai kesetaraan di dalam hukum. Pemerintah kota harus dapat memunculkan solusi kreatif lainnya dengan tanpa memunculkan permasalahan baru. Masyarakat kota juga tidak dapat menyerahkan seluruhnya tugas untuk menyediakan sarana dan prasarana yang baik kepada pemerintah kota tanpa memberikan partisipasi aktif. Kerjasama yang baik antara pemerintah dan warga kota sangat diperlukan untuk menjaga kelangsungan jalur pedestrian di Jakarta.

Sebagai sebuah tulisan sejarah yang disusun dengan menggunakan sumber berita, apa yang dihasilkan dalam tulisan ini masih merupakan hasil penelitian awal. Penelitian ini terbuka untuk dikembangkan dan dilengkapi lebih 
lanjut. Paradigma lain terkait perencanaan dan kebijakan yang dilakukan di Jakarta dapat diuraikan lebih terinci dengan menggunakan sumber data yang lebih lengkap lagi.

\section{DAFTAR PUSTAKA}

Al Karim, Malik, 2019. Analisis Fisik Penggunaan Jalur Pedestrian Sebagai Fasilitas Publik (Studi Kasus: Jalur Pedestrian di Penggal Jalan Pangeran Diponegoro, Kenari, Senen, Jakarta Pusat), Jurnal Planologi Vol.16, No. 1

Doxiadis, C.A. Ekistics, the science of human settlements, Ekistics, Vol. 33, No. 197

Hellman, Jorgen,. Thynell, Marie, \& van Voorst, Roanne, 2018. Jakarta: Claiming Spaces and Rights in the City, Routledge

Hilman Gunung Mulia Pohan, \& Manullang, Okto Risdianto, 2018. Penentuan Prioritas Indikator Dalam Merencanakan Jalur Pejalan Kaki (Studi Kasus: Kawasan Blok M, Jakarta Selatan), Jurnal Pembangunan Wilayah dan Kota, Vol 14, No.3

https://dictionary.cambridge.org/dictionar $\mathrm{y} /$ french-english/trottoir https://www.cnnindonesia.com/gayahidup/20180724192401-277-316699/mengenalpelican-crossing-pengganti-jpo-di-bundaran-hi https://www.cnnindonesia.com/nasional/ 20170804114007-20-232439/bangun-80-kmtrotoar-pemprov-dki-siapkan-rp412-miliar https://www.cnnindonesia.com/nasional/ 20170807132906-20-232973/ahok-dan-mimpitrotoar-10-meter-di-jakarta https://www.merriam-

webster.com/dictionary/pedestrian https://www.viva.co.id/berita/metro/1174 821-bang-yos-kritik-pembangunan-trotoar-aniespemda-dki-lembek

HWp5pQ-Y https://www.youtube.com/watch?v=kKo https://www.youtube.com/watch?v=VdK G3bltdOQ Channel Resmi Pemprov DKI Jakarta Jacobs, Jane, 1992. The Death and Live of Great American Cities, Vintage Books Editions, New York.

Kostof, Spiro, 1992. The City Assembled, Thames \& Hudson Ltd, London.

Kusno, Abidin, 2006. Whither Nationalist Urbanism? Public Life in Governor Sutiyoso's Jakarta, in Lee, Yong-Sook, \& Yeoh, Brenda S.A. 2006. Globalisation and the Politics of Forgetting, Routledge,
Peraturan Menteri Pekerjaan Umum No. 03/PRT/M/2014 Tentang Pedoman Penyediaan dan Pemanfaatan Prasarana dan Sarana Ruang Pejalan Kaki di Kawasan Perkotaan

Petunjuk Perencanaan Trotoar No. 07/T/BNKT/1990

Prima, Taslim Septia, \& Prayogi, Lutfi, Februari 2020. Kajian Perilaku Pejalan Kaki Pada Kawasan Transit Oriented Development (TOD), Jurnal Arsitektur Zonasi, Vol. 3, No.1.

Silver, Christoper, 2008. Planning the Megacity Jakarta in the Twentieth Century, Routledge.

Undang Undang No. 22 Tahun 2009 Tentang Lalu Lintas Angkutan Jalan

Undang Undang No. 26 Tahun 2007 Tentang Penataan Ruang

Wiryomartono, Bagus, 2020. Traditions and Transformations of Habitation in Indonesia, Springer Nature Singapore Pte Ltd, 